\title{
Modulation of hepatotoxicity, DNA fragmentation and gene expression of Solanum nigrum leaves extract in rats treated with silver nanoparticles
}

\author{
Mosaad A. Abdel-Wahhab ${ }^{1 *}$, Helmy M.S. Ahmed ${ }^{2}$, Sekena H. Abdel-Aziem³ ${ }^{3}$ Aziza A. El-Nekeety ${ }^{1}$, \\ Heba A.M. Abd El-Kader ${ }^{3}$, Mohamed S. Abdel-Aziz ${ }^{4}$, Mohamed A. Hamazawy ${ }^{5}$, Hafiza A. Sharaf ${ }^{6}$, \\ Hadeer M. Naguib ${ }^{7}$, Ezzeldeen S. El-Denshary ${ }^{2}$ \\ ${ }^{1}$ Food Toxicology \& Contaminants Dept., National Research Center, Dokki, Cairo, Egypt. ${ }^{2}$ Toxicology \& Pharmacology Dept., Faculty of Pharmacy, Cairo \\ University, Cairo, Egypt. ${ }^{3}$ Cell Biology Dept. National Research Center, Dokki, Cairo, Egypt. ${ }^{4}$ Microbial Chemistry Dept., National Research Center, \\ Dokki, Cairo, Egypt. ${ }^{5}$ Pharmacology \& Toxicology Dept., College of Pharmacy, Misr University for Science and Technology, 6th October City, Egypt. \\ ${ }^{6}$ Pathology Dept., National Research Center, Dokki, Cairo, Egypt, ${ }^{7}$ New Kasr Al-Ainy Hospital, Cairo, Egypt.
}

\begin{tabular}{l} 
ARTICLE INFO \\
\hline Article history: \\
Received on: 04/11/2016 \\
Accepted on: 02/12/2016 \\
Available online: 27/02/2017 \\
\hline Key words: \\
Silver nanoparticles; \\
Solanum nigrum; Liver; \\
DNA fragmentation; gene \\
expression.
\end{tabular}

\begin{abstract}
The current study aimed to determine the antioxidant compounds in Solanum nigrum (S. nigrum) leaves extract, to synthesize silver nanoparticles (AgNPs) and to evaluate the protective role of the extract against the hepatotoxicity and genotoxicity of AgNPs compared to $\mathrm{CCl}_{4}$ in rats. Eight groups of female Sprague-Dawley rats were treated orally for 3 weeks included the control group, $\mathrm{CCl}_{4}$-trared group $(0.1 \mathrm{ml} / \mathrm{kg} \mathrm{b.w}$ twice a week), AgNPs-treated group $\left(50 \mathrm{mg} / \mathrm{kg}\right.$ b.w/day), AgNPs plus $\mathrm{CCl}_{4}$-treated group, $S$. nigrum leaves extract-treated group $(0.5 \mathrm{mg} / \mathrm{kg} \mathrm{b.w})$ and the groups treated with $\mathrm{AgNPs}$ and/or $\mathrm{CCl}_{4}$ plus the extract. The results indicated that the extract was rich in the total phenolic, flavoniods and $\beta$-carotene. The size of synthesized AgNPs was 30$50 \mathrm{~nm}$. Administration of AgNPs and/or $\mathrm{CCl}_{4}$ resulted in severe hepatotoxicity and histological changes, increased DNA fragmentation and down regulation of antioxidant gene expression in liver. The extract was safe and succeeded to mitigate the hazards effect of $\mathrm{AgNPs}$ and/or $\mathrm{CCl}_{4}$. It could be concluded that AgNPs have toxic effects and caution should be taken when they use in food or medical application. S. nigrum extract succeeded to protect the liver due to its higher content of antioxidant compounds.
\end{abstract}

\section{INTRODUCTION}

Recently, silver nanoparticles (AgNPs) are widely used in different medical products and hygiene application due to their antibacterial (Ayala-Núnez et al., 2009), antiviral (Mehrbod et al., 2009) and antifungal properties (Kim et al., 2008; AbdelAziz et al., 2014). AgNPs are also used in the disinfection of drinking water (Lv et al., 2009), swimming pools antifouling (Yang et al., 2009), bedding, toothpaste, washing machines, shampoo, nipples and nursing bottles, deodorants, fabrics, kitchen utensils, toys, filters (MacNee and Donaldson, 2003; Jia et al., 2009) and as a promising antibacterial additive to

\footnotetext{
* Corresponding Author

E-mail: mosaad_abdelwahhab@yahoo.com
}

water-based paints (Holtz et al., 2012). AgNPs also modulate cytokine so they promote wound healing (Wong et al., 2009). Despite the widespread use of the products containing AgNPs, the subchronic and chronic toxicity data of AgNPs remain rare. Several biological and medical reports suggested that silver ions are released into the blood medical devices and accumulate in the liver and kidney resulting in liver and kidney toxicity which may ultimately lead to death (Park et al., 2010). Thus, it is supposed that AgNPs have toxicity however the mechanism of their toxicity is not clear (Tang and $\mathrm{Xi}, 2008$ ). Several reports suggested that AgNPs showed more toxicity than other metals such as nickel, iron, aluminum and manganese (Braydich-Stolle et al., 2005). However, the lack of exposure data on AgNPs in the workplace and their released from the products or into the environment makes it difficult to assess the risks of using these materials. 
Several techniques have been used for synthesize of AgNPs including the chemical and physical methods which use huge amount of toxic chemicals with high temperature, so the use of a safe alternative method is of great demand (Quaresma et al., 2009). AgNPs can be synthesized by green chemistry using natural organisms which offered a reliable, nontoxic simple, and ecofriendly (Abdel-Aziz et al., 2014). Therefore, during the last years researches have used the biological systems for the synthesized of nanoparticle (Tsibakhashvili et al., 2010) using microorganisms, enzyme and plant or plant extract as alternatives methods (Nair and Pradeep, 2002). Moreover, the biosynthesis of AgNPs by plant surpasses the other biological methods (Willner et al., 2006). The green synthesis of AgNPs using the leaves broth of Argimone maxicana produced particles sized of $20 \mathrm{~nm}$ effective against many bacterial and fungal pathogens (Khandelwal et al., 2010). The aims of the current study were to: (1) determination of total phenolic content, total flavonoids and $\beta$-carotene of $S$. nigrum leaves extract, (2) to synthesis and characterized AgNPs using $S$. nigrum leaves extract, (3) to evaluate the hepatotoxicity and cytotoxicity of AgNPs compared to $\mathrm{CCl}_{4}$ and (4) to evaluate the possible protective role of $S$. nigrum leaves extract against AgNPsinduced hepatotoxicity in rats

\section{MATERIALS AND METHODS}

\section{Chemicals and Kits}

Carbon tetrachloride $\left(\mathrm{CCl}_{4}\right)$ was supplied from Morgan, Cairo, Egypt. Alanine aminotransferase (ALT) and Aspartate aminotransferase (AST) kits were purchased from Spectrumdiagnostics Co. (Cairo, Egypt). Alkaline phosphatase (ALP), Gamma Glutamyltransferase (GGT), creatinine, urea, uric acid, catalase (CAT), glutathione peroxidase (GPx), total antioxidant capacity (TAC), tumor necrosis factor alfa (TNF- $\alpha$ ), nitric oxide (NO), malondialdehyde (MDA) kits were purchased from Biodiagnostic Co. (Giza, Egypt). All other chemicals used throughout the experiments were of the highest analytical grade available.

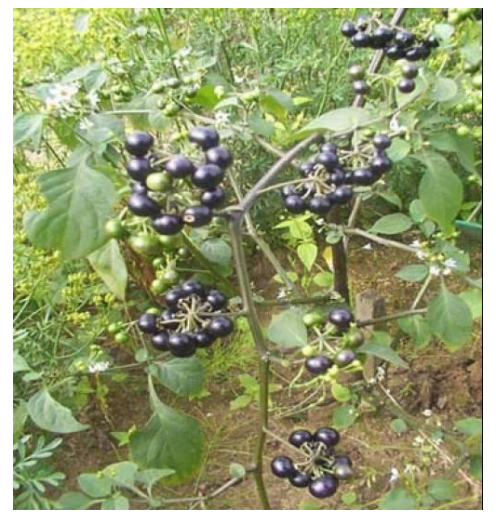

Fig. 1: S. nigrum plant.

\section{Preparation of $S$. nigrum extract}

This process has been performed after collecting the $S$. nigrum (Family: Solanaceae; Fig. 1) leaves during late summer
2015 from canal bank habitat around agriculture area in Dekernis, Dakahlia Governorate, Egypt. The green leaves were thoroughly washed with distilled water to get rid of any strange materials especially dust and dirt. Twenty g of clean leaves were boiled in $50 \mathrm{ml}$ distilled water in Erlenmeyer flask of 500-ml volume for 30 min and the leaf debris were removed by filtration through Whatman filter paper no. 1 and the produced extract was subjected to freeze drying.

\section{Determination of total phenol and total flavonoid content of $S$. nigrum extract}

Total phenol was determined in the $S$. nigrum leaves extract by Folin-Ciocalteau reagent in alkaline medium and was expressed as gallic acid equivalents (Singh et al., 2002). However, total flavonoid content was determined according to Kim et al. (2003) and was expressed as catechin equivalents.

\section{Determination of $\beta$-Carotene}

The determination of $\beta$-carotene in the plant extract was carried out according to the method described by Wettasinghe and Shahidi (1999). Briefly, $2 \mathrm{ml}$ of $\beta$-carotene solution $(0.2 \mathrm{mg} / \mathrm{ml}$ in chloroform) were pipetted into a round-bottom flask containing 20 $\mu 1$ linoleic acid and $200 \mu 1$ Tween 20 . The solvent was evaporated from the mixture at $40{ }^{\circ} \mathrm{C}$ for $10 \mathrm{~min}$. A volume of $100 \mathrm{ml}$ distilled water was added immediately and after the mixture was agitating vigorously, $5 \mathrm{ml}$ aliquots of the resulting emulsion were transferred into test tubes containing different concentration (5-20 $\mathrm{mg} / \mathrm{ml}$ ) of the extracts. The mixture was vortexed and placed in a water bath at $50{ }^{\circ} \mathrm{C}$ for $2 \mathrm{~h}$ while the absorbance of the tested sample was repeatedly measured every $15 \mathrm{~min}$ at $470 \mathrm{~nm}$ using a UV-VIS spectrophotometer against a blank solution contained the same concentration of sample without $\beta$-carotene. All determinations were performed in triplicates and the total antioxidant activity was calculated based on the following equation:

$$
\mathrm{AA}=1-\left(\mathrm{A}_{0}-\mathrm{A}_{\mathrm{t}}\right) /\left(\mathrm{A}^{0}{ }_{0}-\mathrm{A}_{0}^{\mathrm{t}}\right)
$$

where AA is antioxidant activity, $\mathrm{A}_{0}$ and $\mathrm{A}_{0}^{0}$ are the absorbance values measured at initial time of the incubation for samples and control, respectively, while $A_{t}$ and $A_{0}^{t}$ are the absorbance in the samples and control at $\mathrm{t}=120 \mathrm{~min}$.

\section{Biosynthesis of Silver nanoparticles (AgNPs)}

AgNPs were biologically synthesized from $S$. nigrum (Family: Solanaceae) leaves extract (Abdel-Aziz et al., 2014; Dwivedi and Gopal, 2011). Fifty milliliter of silver nitrate solution $(3 \mathrm{mM})$ were prepared in stopper conical flask and $5 \mathrm{ml}$ of the previously prepared leaf extract were added and left at room temperature for $1 \mathrm{~h}$ and the produced brownish yellow or reddish brown color indicate the biosynthesis of AgNPs.

\section{Characterization of AgNPs \\ $U V$-vis adsorbance spectroscopy analysis}

The bioreduction of silver nitrate $\left(\mathrm{AgNO}_{3}\right)$ to $\mathrm{AgNPs}$ was monitored periodically by UV-vis spectroscopy (Shimazu 
2401PC) after the dilution of the samples with deionized water as described by Raut et al. (2010) UV-vis spectrograph of AgNPs was recorded by using a quartz cuvette with water as reference and the readings were recorded at a scanning speed of 200 to $800 \mathrm{~nm}$ (Leela and Vivekanandan, 2008).

\section{TEM analysis of AgNPs}

AgNPs were sampled by TEM analysis using JEOL model 1200 EX electron microscope. The samples were prepared by placing a drop of the suspension of AgNPs solutions on carboncoated copper grids. After the evaporation of water, the samples on the grids were allowed to dry for 4 minutes and the shape and size of AgNPs were determined from TEM micrographs (Elavazhagan and Arunachalam, 2011).

\section{Experimental animals}

Three-month old sexually mature female SpragueDawley rats (150-160 gm) were purchased from Animal House Colony, Misr University for Science and Technology, 6 October City, Giza, Egypt. Animals were maintained on the specified diet and housed in filter top polycarbonate cages in a room free from any source of chemical contamination, artificially illuminated (12 $\mathrm{h}$ dark/light cycle) and thermally controlled $\left(25 \pm 1{ }^{\circ} \mathrm{C}\right)$ at the Animal House Lab, Misr University for Science and Technology. All animals were received humane care in compliance with the guidelines of the Animal Care and Use Committee of Misr University for Science and Technology, Giza, Egypt and the National Institute of Health (NIH publication 86-23 revised 1985).

\section{Experimental design}

Animals were divided into eight groups (10 rats/group) and were maintained on their respective diet and treated orally for 3 weeks as follows: group1; normal control animals which fed on basal diet and water without any treatment, group 2; animals treated with $\mathrm{CCl}_{4}$ suspended in corn oil $(0.1 \mathrm{ml} / \mathrm{kg} \mathrm{b.w})$ twice a week (Feng et al., 2010), group 3; rats treated with aqueous solution of AgNPs (50 mg/kg b.w), group 4; rats were treated with AgNPs plus $\mathrm{CCl}_{4}$, group 5; rats treated with water extract of $S$. nigrum leaves $(0.5 \mathrm{mg} / \mathrm{kg}$ b.w), group 6, rats treated with AgNPs plus $S$. nigrum leaves extract, group 7; rats were treated with $S$. nigrum leaves extract plus $\mathrm{CCl}_{4}$, group 8; rats were treated with $\mathrm{AgNPs}$ and $\mathrm{CCl}_{4}$ plus $S$. nigrum leaves extract.

The animals were observed daily for signs of toxicity during the experimental period. At the end of the treatment period (i.e. day 21), all animals were fasted for $12 \mathrm{hr}$, then blood samples were collected via the retro-orbital venous plexus under ether anesthesia. The blood samples were used for the determination of ALT, AST, ALP, GGT, createnine, uric acid, urea, NO and TNF- $\alpha$ according to the manufacture instaurations. After the collections of blood samples, animals were sacrificed and samples of liver of each animal were dissected, weighted and homogenized in phosphate buffer (PH 7.4) to give 20\% w/v homogenate (Lin et al., 1998). This homogenate was centrifuged at $1700 \mathrm{rpm}$ and $4{ }^{\circ} \mathrm{C}$ for $10 \mathrm{~min}$, the supernatant was stored at $\left(-70^{\circ} \mathrm{C}\right)$ until analysis and it used for the determination of MDA. This supernatant was further diluted with phosphate buffer solution to give $2 \%$ and $5 \%$ dilutions for determination of hepatic GPx (2\%), TAC and CAT $(0.5 \%)$ activities. Samples of liver were collected, excised and fixed in natural formalin and were hydrated in ascending grades of ethanol, cleared in xylene and embedded in paraffin. Sections ( $5 \mu \mathrm{m}$ thick) were cut and stained with hematoxylin and eosin (HX \& E) for the histological examination (Drury \& Wallington 1980). Other samples of liver tissues were collected and stored at $-70{ }^{\circ} \mathrm{C}$ for cytotoxucity studies.

\section{DNA fragmentation by diphenylamine assay (DPA)}

Liver tissues were lysed in $0.5 \mathrm{ml}$ of lysis buffer containing $10 \mathrm{mM}$ tris- $\mathrm{HCl}(\mathrm{pH} 8), 1 \mathrm{mM}$ EDTA, $0.2 \%$ triton X100 , centrifuged at $10,000 \mathrm{rpm}$ for $15 \mathrm{~min}$ at $4^{\circ} \mathrm{C}$ to separate intact chromatin in the pellet from fragmented/damaged DNA in the supernatant. The pellets were resuspended in $0.5 \mathrm{~N}$ perchloric acid (P) and $5.5 \mathrm{~N}$ perchloric acid was added to supernatants (S) to attain a final concentration of $0.5 \mathrm{~N}$. The samples were incubated at $90{ }^{\circ} \mathrm{C}$ for $20 \mathrm{~min}$ and centrifuged at $10000 \mathrm{rpm}$ for $10 \mathrm{~min}$ to remove proteins. Subsequently, $160 \mathrm{ml}$ of diphenylamine (DPA) solution [150 mg DPA in $10 \mathrm{ml}$ glacial acetic acid, $150 \mathrm{ml}$ of sulfuric acid and $50 \mathrm{ml}$ acetaldehyde $(16 \mathrm{mg} / \mathrm{ml})]$ was added to each sample and incubated at room temperature for $24 \mathrm{~h}$ (Gibb et al., 1997). Absorbance was measured at $600 \mathrm{~nm}$ using a UV double beam spectrophotometer (Shimdazu 160 A; Shimadzu Co., Japan). The proportion of fragmented DNA was calculated from absorbance reading at $600 \mathrm{~nm}$. The proportion of fragmented DNA was calculated from absorbance reading at $600 \mathrm{~nm}$ using the equation:

DNA fragmentation $=$ OD of fragmented DNA (supernatant) $/$ [OD of fragmented DNA (supernatant) + OD of intact DNA (pellet) $] \times 100$

\section{DNA gel electrophoresis laddering assay}

Apoptotic DNA fragmentation was qualitatively analyzed by detecting the laddering pattern of nuclear DNA according to $\mathrm{Lu}$ et al. (2002). In brief, liver tissues were homogenized, washed overnight at $37^{\circ} \mathrm{C}$ in PBS and lysed in 0.5 $\mathrm{ml}$ of DNA extraction buffer $(50 \mathrm{mM}$ Tris- $\mathrm{HCl}, 10 \mathrm{mM}$ EDTA. $0.5 \%$ Triton, and $100 \mu \mathrm{g} / \mathrm{ml}$ proteinase $\mathrm{K}, \mathrm{pH} 8.0$ ). The lysate was then incubated with $100 \mu \mathrm{g} / \mathrm{ml}$ DNase-free RNase for $2 \mathrm{~h}$ at $37{ }^{\circ} \mathrm{C}$ followed by three extractions of an equal volume of phenol/chloroform $(1: 1 \mathrm{v} / \mathrm{v})$ and a subsequent re-extraction with chloroform by centrifuging at $15,000 \mathrm{rpm}$ for $5 \mathrm{~min}$ at $4{ }^{\circ} \mathrm{C}$. The extracted DNA was precipitated in 2 volume of ice-cold $100 \%$ ethanol with $1 / 10$ volume of $3 \mathrm{M}$ sodium acetate, $\mathrm{pH} 5.2$ at $-20^{\circ} \mathrm{C}$ for $1 \mathrm{~h}$, followed by centrifuging at $15,000 \mathrm{rpm}$ for $15 \mathrm{~min}$ at $4{ }^{\circ} \mathrm{C}$. After washing with 70\% ethanol, the DNA pellet was air-dried and dissolved in $10 \mathrm{mM}$ Tris-HCl/1 mM EDTA, $\mathrm{pH}$ 8.0. The DNA was then electrophoresed on $1.5 \%$ agarose gel and stained with ethidium bromide in Tris/acetate/EDTA (TAE) buffer ( $\mathrm{pH} 8.5,2$ mM EDTA, and $40 \mathrm{mM}$ Tris-acetate). A 100-bp DNA ladder (Invitrogen, USA) was included as a molecular size marker and 
DNA fragments were visualized and photographed by exposing the gels to ultraviolet transillumination.

\section{Semi-quantitative -PCR Isolation of total RNA}

RNA was isolated from hepatocytes by the standard TRIzol® Reagent (Invitrogen ${ }^{\mathrm{TM}}$, Carlsbad, CA, USA) extraction method. RNA was dissolved in diethylpyrocarbonate (DEPC)water by passing solution a several times through a pipette tip. To digest DNA residues, RNA was treated with $1 \mathrm{U}$ of RQ1 RNasefree DNase and re-suspended in DEPC water. Purity of RNA was assessed by the 260/280 $\mathrm{nm}$ ratio (between 1.8 and 2.1 ). Integrity was confirmed with ethidium bromide-stain analysis of $28 \mathrm{~S}$ and $18 \mathrm{~S}$ bands by formaldehyde agarose gel electrophoresis. Aliquots were used immediately for reverse transcription (RT).

\section{Reverse transcription and semi-quantitative polymerase chain reaction (sq-PCR)}

To perform a semi-quantitative-PCR, $1 \mu \mathrm{g}$ of isolated total RNA was reverse-transcribed into cDNA with an RT PreMix Kit (iNtRON Biotechnology, Korea) according to the manufacturer's instructions. In brief, cDNA synthesis was carried out by PCR (Thermo-Cycler 9700, Germany) at $45{ }^{\circ} \mathrm{C}$ for $1 \mathrm{~h}$ and $95{ }^{\circ} \mathrm{C}$ for $5 \mathrm{~min}$. Then, the PCR mixture consisted of cDNA $2 \mu \mathrm{l}$, $10 \times$ PCR buffer $2 \mu \mathrm{l}$, dNTPs $2 \mu \mathrm{l}$, Taq DNA polymerase $0.2 \mu \mathrm{l}$, forward/reverse primer $0.2 \mu 1$ and $0.1 \%$ diethylpyrocarbonate water for final volume $20 \mu \mathrm{l}$ were amplified as follows: denaturation at $95{ }^{\circ} \mathrm{C}$ for $5 \mathrm{~min}$ and $94{ }^{\circ} \mathrm{C}$ for $30 \mathrm{~s}$, annealing at $50{ }^{\circ} \mathrm{C}$ for $30 \mathrm{~s}$, extension at $74{ }^{\circ} \mathrm{C}$ for $1 \mathrm{~min}$ ( 35 cycles) and final extension at 72 ${ }^{\mathrm{O}} \mathrm{C}$ for $10 \mathrm{~min}$. The primers GPx (GPx-F: 5'CTCTCCGCGGTGGCACAGT-3', GPx-R: 5'CCACCACCGGGTCGGACATAC-3) (GenBank: M21210). The primer $\mathrm{Cu}-\mathrm{Zn}$ SOD $\left(\mathrm{Cu}-\mathrm{Zn}\right.$ SOD- $\mathrm{F}: 5^{\prime}-$ GCAGAAGGCAAGCGGTGAAC-3', Cu-Zn SOD- R: 5'TAGCAGGACAGCAGATGAGT-3') (GenBank: X05634) genes were normalized on the bases of GAPDH GAPDH -F: 5'CAAGGTCATCCATGACAACTTTG-3', GAPDH-R: 5'GTCCACCACCCTGTTGCTGTAG -3' (Wiame et al., 2000).

\section{Semi-quantitative -PCR}

The PCR product was run on a $1.5 \%$ agarose gel in Trisborate-EDTA buffer and visualized over a UV Trans-illuminator. The ethidium bromide-stained gel bands were scanned and the signal intensities were quantified by the computerized Gel-Pro (version 3.1 for window 3). The ratio between the levels of the target gene amplification product and the GAPDH (internal control) was calculated to normalize for initial variation in sample concentration as a control for reaction efficiency. All PCRs were independently replicated three times (Raben et al., 1996).

\section{Statistical analysis}

All data were statistically analyzed by analysis of Variance (ANOVA) using the General Linear Model Procedure of the Statistical Analysis System (SAS, 1982). The significance of the differences among treatment groups was determined by Waller-Duncan k-ratio (Waller and Duncan, 1969). All statements of significance were based on probability of $\mathrm{P} \leq 0.05$.

\section{RESULTS}

The results of the current study revealed that the aqueous extract of $S$. nigrum leaves is a promise antioxidant agent due to the higher content of total phenolic and flavoniods (Fig. 2). The data revealed that the extract contained $75.2 \pm 2.35 \mathrm{mg} / \mathrm{g}$ gallic acid equivalent total phenol and $13.21 \pm 1.62 \mathrm{mg} / \mathrm{g}$ gallic acid equivalent total flavonoids. Moreover, the results of $\beta$-carotene oxidation (Fig. 3) demonstrated also a higher antioxidant activity and the recorded $\mathrm{IC}_{50}$ values of $\beta$-carotene were $16.23 \pm 1.1 \mu \mathrm{g} /$ $\mathrm{ml}$ at the lowest concentration of the aqueous extract $(5 \mathrm{mg} / \mathrm{L})$ and increased to $52.16 \pm 1.16 \mu \mathrm{g} / \mathrm{ml}$ at the highest concentration of the extract $(20 \mathrm{mg} / \mathrm{L})$.

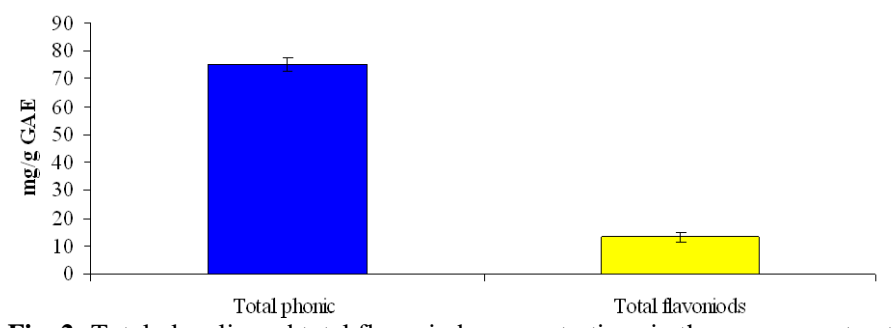

Fig. 2: Total plenolic and total flavoniods concentrations in the aqueous extract of $S$. nigrum leaves

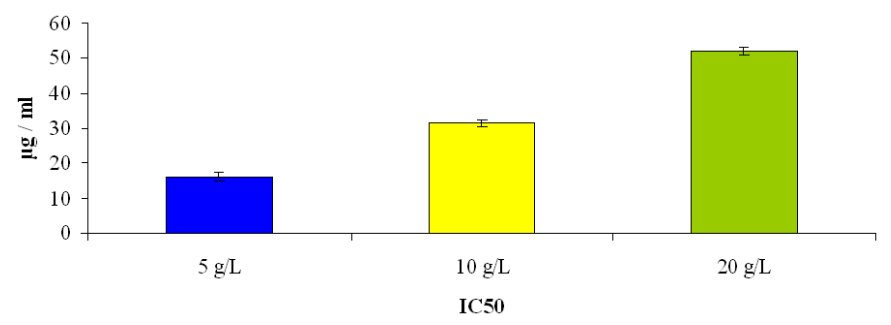

Fig. 3: $\mathrm{IC}_{50}$ of $\beta$-carotene content in the aqueous extract of $S$. nigrum leaves

\section{Synthesis and characterization of AgNPs}

The results of AgNPs synthesize showed that addition of $200 \mu \mathrm{g}$ of the $S$. nigrum leaves extract to $50 \mathrm{ml}$ of $5 \mathrm{mM}$ aqueous silver nitrate $\left(\mathrm{AgNO}_{3}\right)$ and the incubation overnight at $40{ }^{\circ} \mathrm{C}$ in dark resulted in the formation of the brown solution which indicated the biosynthesis of AgNPs (Fig. 4a). Spectrophotometric study of the produced brown colored solution through the rage spectra 190-800 nm using Shimadzu UV/VIS 2401PC showed a maximum absorption at 450-500 $\mathrm{nm}$ (Fig. 4b). The TEM analysis revealed that the size of AgNPs ranged between 30 and $50 \mathrm{~nm}$ (Fig. 4c). The results of in vivo study indicated that the treatment with AgNPs and/or $\mathrm{CCl}_{4}$ resulted in a significant increase in serum AST, ALT, ALP, GGT, creatinine, uric acid, urea, TNF- $\alpha$ and NO (Table 1). Animals treated with $S$. nigrum leaves extract showed a significant increase in GGT and a significant decrease in urea, TNF- $\alpha$ and NO however, the other biochemical parameters were comparable to the control group. 

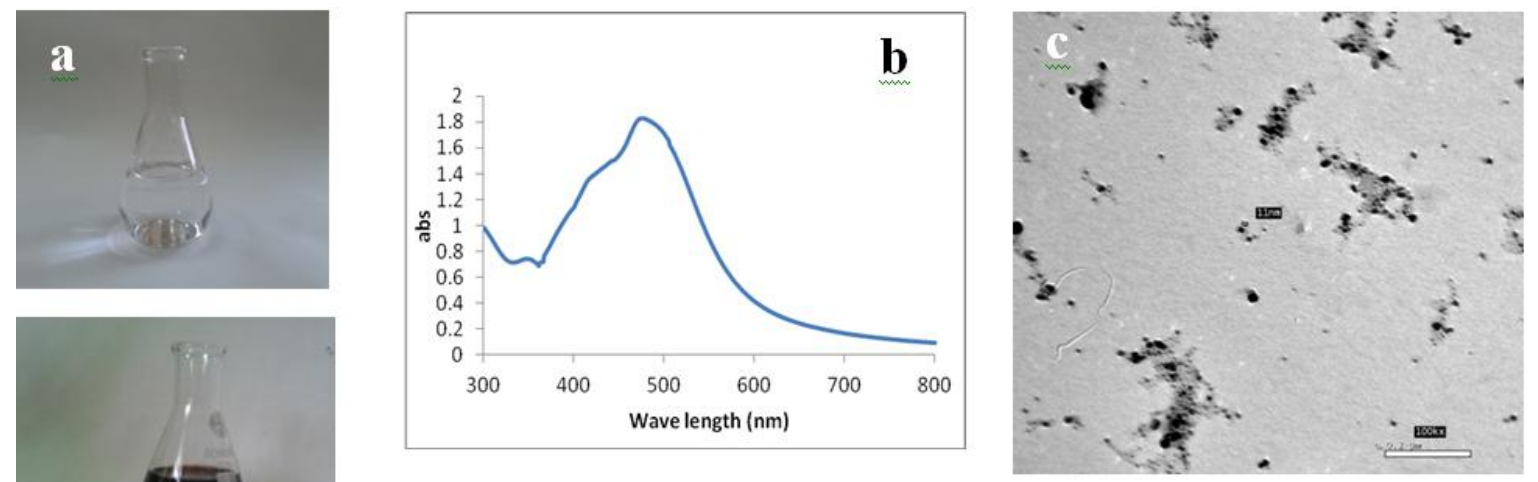

Fig. 4: Changes of the silver nitrate colour to reddish-brown after the addition of $S$. nigrum leaves extract when added to silver nitrate (3 mM) (a) and the produced solution showed Uv/Vis absorbance at $460 \mathrm{~nm}$ (b). Transimittance electron microscope (TEM) image of the prepared AgNPs revealed that the produced particles were in the nano form and their sizes ranged from 2 to $16 \mathrm{~nm}(\mathbf{c})$.

Table 1: Effects of S. nigrum leaves extract on serum biochemical parameters in rats treated with $\mathrm{AgNPs}$ and/or $\mathrm{CCl}_{4}$

\begin{tabular}{|c|c|c|c|c|c|c|c|c|}
\hline $\begin{array}{ll} & \text { Groups } \\
\text { parameters } & \\
\end{array}$ & Control & AgNPs & $\mathrm{CCl}_{4}$ & $\mathrm{AgNPs}+\mathrm{CCl}_{4}$ & SNLE & AgNPs + SNLE & $\mathrm{CCl}_{4}+\mathrm{SNLE}$ & $\begin{array}{c}\mathrm{AgNPs}+\mathrm{CCl}_{4}+ \\
\text { SNLE }\end{array}$ \\
\hline AST (U/L) & $88.20 \pm 1.52^{\mathrm{a}}$ & $109.80 \pm 2.39^{\mathrm{c}}$ & $157.40 \pm 9.39^{b}$ & $193.86 \pm 1.28^{\mathrm{d}}$ & $90.14 \pm 2.95^{\mathrm{a}}$ & $87.43 \pm 0.84^{\mathrm{a}}$ & $93.40 \pm 2.27^{\mathrm{a}}$ & $89.32 \pm 2.09^{\mathrm{a}}$ \\
\hline ALT (U/L) & $20.20 \pm 1.49^{\mathrm{a}}$ & $26.43 \pm 2.23^{c}$ & $42.80 \pm 3.34^{\mathrm{b}}$ & $67.60 \pm 2.77^{\mathrm{d}}$ & $21.143 \pm 2.51^{\mathrm{a}}$ & $17.29 \pm 1.38^{\mathrm{a}}$ & $27.60 \pm 1.99^{\mathrm{c}}$ & $28.0 \pm 1.64^{\mathrm{c}}$ \\
\hline ALP (U/L) & $119.61 \pm 8.84^{\mathrm{a}}$ & $145.17 \pm 9.77^{\mathrm{c}}$ & $478.83 \pm 38.47^{\mathrm{b}}$ & $482.03 \pm 11.33^{\mathrm{b}}$ & $120.84 \pm 1.83^{\mathrm{a}}$ & $207.92 \pm 5.29^{\mathrm{d}}$ & $157.71 \pm 19.41^{\mathrm{e}}$ & $184.28 \pm 12.75^{\mathrm{f}}$ \\
\hline GGT (mg/dl) & $9.42 \pm 1.30^{\mathrm{a}}$ & $23.14 \pm 1.53^{\mathrm{c}}$ & $44.4 \pm 1.86^{\mathrm{b}}$ & $52.36 \pm 1.62^{\mathrm{e}}$ & $11.00 \pm 1.13^{\mathrm{d}}$ & $13.17 \pm 1.03^{\mathrm{d}}$ & $15.20 \pm 1.20^{\mathrm{f}}$ & $18.20 \pm 1.32^{\mathrm{g}}$ \\
\hline Creatinine $(\mathrm{mg} / \mathrm{dl})$ & $1.15 \pm 0.12^{\mathrm{a}}$ & $3.12 \pm 0.49^{c}$ & $5.95 \pm 0.64^{\mathrm{b}}$ & $9.18 \pm 0.07^{\mathrm{e}}$ & $1.14 \pm 0.07^{\mathrm{a}}$ & $2.18 \pm 0.04^{\mathrm{d}}$ & $3.19 \pm 0.08^{\mathrm{c}}$ & $4.18 \pm 0.06^{\mathrm{f}}$ \\
\hline Uric acid (mg/dl) & $2.34 \pm 0.45^{\mathrm{a}}$ & $3.05 \pm 0.36^{\mathrm{c}}$ & $5.78 \pm 0.29^{\mathrm{b}}$ & $8.16 \pm 0.38^{d}$ & $2.32 \pm 0.28^{\mathrm{a}}$ & $2.46 \pm 0.21^{\mathrm{a}}$ & $3.09 \pm 0.39^{\mathrm{c}}$ & $4.86 \pm 0.34^{\mathrm{e}}$ \\
\hline urea $(\mathrm{mg} / \mathrm{dl})$ & $29.99 \pm 5.13^{\mathrm{a}}$ & $34.74 \pm 1.01^{\mathrm{c}}$ & $46.84 \pm 3.50^{b}$ & $58.37 \pm 2.70^{\mathrm{e}}$ & $25.49 \pm 1.31^{\mathrm{d}}$ & $29.79 \pm 2.68^{\mathrm{a}}$ & $32.79+8.75^{\mathrm{c}}$ & $35.33 \pm 1.26^{\mathrm{c}}$ \\
\hline $\mathrm{TNF}-\alpha(\mathrm{mg} / \mathrm{dl})$ & $74.60 \pm 0.93^{\mathrm{a}}$ & $91.57 \pm 0.20^{\mathrm{c}}$ & $112.94 \pm 0.84^{\mathrm{b}}$ & $135.20 \pm 1.74^{\mathrm{f}}$ & $69.71 \pm 3.57^{\mathrm{d}}$ & $84.57 \pm 3.29^{\mathrm{e}}$ & $97.00 \pm 1.09^{\mathrm{c}}$ & $100.00 \pm 2.22^{\mathrm{c}}$ \\
\hline $\mathrm{NO}(\mu \mathrm{mol} / \mathrm{L}$ & $710 \pm 34.06^{\mathrm{a}}$ & $750 \pm 29.44^{\mathrm{c}}$ & $919.16 \pm 44.91^{\mathrm{b}}$ & $994 \pm 22.49^{\mathrm{e}}$ & $665 \pm 44.03^{d}$ & $718.57 \pm 77.44^{\mathrm{a}}$ & $725 \pm 20.12^{\mathrm{a}}$ & $788 \pm 26.91^{\mathrm{f}}$ \\
\hline
\end{tabular}

Within each raw, means superscript with different letters (a,b,c...) are significantly different $(\mathrm{P} \leq 0.05)$.

SNLE: S. nigrum leaves extract.

Table 2: Effects of S. nigrum leaves extract on MDA and antioxidant parameters in liver of rats treated with AgNPs and/or $\mathrm{CCl}_{4}$

\begin{tabular}{|c|c|c|c|c|}
\hline $\begin{array}{c}\text { Parameters } \\
\text { Groups }\end{array}$ & $\begin{array}{c}\text { MDA } \\
\text { (nmol/g tissue) }\end{array}$ & $\begin{array}{c}\text { TAC } \\
\text { (nmol/g tissue) }\end{array}$ & $\begin{array}{c}\text { CAT } \\
\text { (nmol/g tissue) }\end{array}$ & $\begin{array}{c}\text { GSH } \\
\text { (mg/g tissue) } \\
\end{array}$ \\
\hline Control & $69.45 \pm 5.25^{\mathrm{a}}$ & $528.50 \pm 13.35^{\mathrm{a}}$ & $763.33 \pm 20.67^{\mathrm{a}}$ & $6.92 \pm 0.38^{\mathrm{a}}$ \\
\hline AgNPs & $85.72 \pm 8.16^{\mathrm{c}}$ & $470.43 \pm 1.81^{\mathrm{c}}$ & $608.00 \pm 6.76^{\mathrm{c}}$ & $4.44 \pm 0.38^{\mathrm{c}}$ \\
\hline $\mathrm{CCl}_{4}$ & $101.23 \pm 8.83^{b}$ & $421.99 \pm 12.17^{b}$ & $503.00 \pm 27.81^{\mathrm{b}}$ & $3.64 \pm 0.24^{\mathrm{b}}$ \\
\hline $\mathrm{CCl}_{4}+\mathrm{AgNPs}$ & $113.97 \pm 8.81^{\mathrm{e}}$ & $361.60 \pm 2.50^{f}$ & $403.20 \pm 5.31^{\mathrm{e}}$ & $2.25 \pm 1.09^{\mathrm{f}}$ \\
\hline SNLE & $61.39 \pm 8.56^{\mathrm{d}}$ & $593.50 \pm 3.27^{\mathrm{d}}$ & $891.50 \pm 9.061^{d}$ & $7.92 \pm 0.66^{\mathrm{d}}$ \\
\hline AgNPs + SNLE & $70.90 \pm 6.61^{\mathrm{a}}$ & $502.43 \pm 3.06^{\mathrm{e}}$ & $760.57 \pm 17.11^{\mathrm{a}}$ & $5.02 \pm 0.97^{\mathrm{e}}$ \\
\hline $\mathrm{CCl}_{4}+\mathrm{SNLE}$ & $73.16 \pm 8.35^{\mathrm{a}}$ & $492.33 \pm 10.96^{\mathrm{g}}$ & $663.83 \pm 16.79^{f}$ & $4.36 \pm 1.46^{\mathrm{c}}$ \\
\hline $\mathrm{CCl}_{4}+\mathrm{AgNPs}+\mathrm{SNLE}$ & $89.52 \pm 6.40^{f}$ & $435.20 \pm 24.54^{b}$ & $652.00 \pm 31.47^{\mathrm{f}}$ & $3.61 \pm 0.46^{\mathrm{b}}$ \\
\hline
\end{tabular}

Within each column, means superscript with different letters $(a, b, c \ldots)$ are significantly different $(\mathrm{P} \leq 0.05)$.

SNLE: S. nigrum leaves extract.

Moreover, the extract succeeded to induce a significant improvement in the groups treated with AgNPs and/or $\mathrm{CCl}_{4}$ towards the normal level of the control group (Table 1).

Animals treated with AgNPs and/or $\mathrm{CCl}_{4}$ showed a significant increase in hepatic MDA accompanied with a significant decrease in GPx, TAC and CAT (Table 2). However treatment with the extract alone resulted in a significant increase in
GPx, TAC and CAT accompanied with a significant decrease in MDA level.

The combined treatment with the extract plus AgNPs and/or $\mathrm{CCl}_{4}$ resulted in a significant improvement in the antioxidant enzymes activity and MDA level towards the control level although it did not normalize these parameters except MDA in the group treated with the extract plus AgNPs (Table 2). 


\section{DNA fragmentation by diphenylamine (DPA)}

The results presented in Table (3) indicate that treatment with $\mathrm{CCl}_{4}$ and/or AgNPs induced DNA damage in liver cells as evaluated by measuring the level of fragmented DNA colorimetric using diphenylamine (DPA). The recorded percentage of DNA fragmentation in liver cells of rats treated with $\mathrm{CCl}_{4}$ and AgNPs were high $(33.2 \pm 2.9$ and $25.9 \pm 1.8$, respectively) compared to the untreated control group $(8.0 \pm 0.54)$. Meanwhile, treatment with $S$. nigrum extract decreased the percentage of DNA fragmentation as compared to the control $(7.1 \pm 0.69)$. Co-treatment with $S$. nigrum extract plus AgNPs and/or $\mathrm{CCl}_{4}$ succeeded to induce a significant improvement in the percentage of DNA fragmentation towards the control value $(15.7 \pm 0.42,16.2 \pm 0.77$ and $21.9 \pm 0.86)$ although the percentage of DNA fragmentation was still higher than the control (Table 3). Moreover, DNA fragmentation in different treatment groups was also detected by gel electrophoresis as a DNA ladder representing a series of fragments (Fig. 5).

Table 3: Effect of $S$. nigrum extract on the percentage of DNA fragmentation in liver of rats treated with $\mathrm{AgNPs}$ and/or $\mathrm{CCl}_{4}$.

\begin{tabular}{|c|c|c|}
\hline Treatment & $\begin{array}{c}\text { DNA fragmentation } \\
\%(\mathrm{M} \pm \mathrm{SE})\end{array}$ & $\begin{array}{c}\% \text { of Change } \\
\text { compared to control }\end{array}$ \\
\hline Control & $8.0 \pm 0.54^{\mathrm{a}}$ & -- \\
\hline $\mathrm{AgNPs}$ & $25.9 \pm 1.8^{\mathrm{c}}$ & +17.9 \\
\hline $\mathrm{CCl}_{4}$ & $33.2 \pm 2.9^{\mathrm{d}}$ & +25.2 \\
\hline $\mathrm{AgNPs}+\mathrm{CCl}_{4}$ & $36.6 \pm 1.8^{\mathrm{d}}$ & +28.6 \\
\hline SNLE & $7.1 \pm 0.69^{\mathrm{a}}$ & -0.9 \\
\hline AgNPs + SNLE & $15.7 \pm 0.42^{\mathrm{b}}$ & +7.7 \\
\hline $\mathrm{CCl}_{4}+\mathrm{SNLE}$ & $16.2 \pm 0.77^{\mathrm{b}}$ & +8.2 \\
\hline $\mathrm{AgNPs}+\mathrm{CCl}_{4}+\mathrm{SNLE}$ & $21.9 \pm 0.86^{\mathrm{c}}$ & +13.9 \\
\hline
\end{tabular}

$\begin{array}{lllllllllllllllll}M & 1 & 2 & 3 & 4 & 5 & 6 & 7 & 8 & 9 & 10 & 11 & 12 & 13 & 14 & 15 & 16\end{array}$

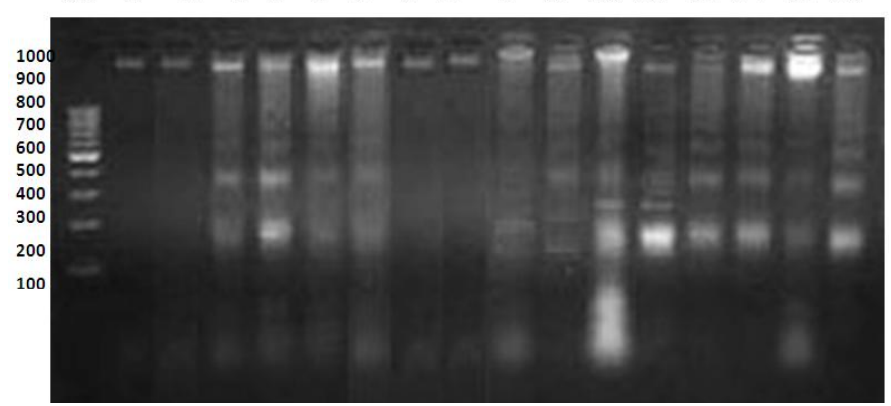

Fig. 5: Effects of SNLE on DNA fragmentation in hepatic tissue of rats treated with $\mathrm{AgNPs}$ and/or $\mathrm{CCl}_{4}$. Agarose gel electrophoretic pattern of DNA isolated from liver tissue of different groups. Lane M: 100-bp ladder marker, Lanes 1,2: Control, Lanes 3,4: $\mathrm{CCl}_{4}$ Lanes 5,6: AgNPs, Lanes 7,8: SNLE, Lanes 9,10: AgNPs plus SNLE, Lanes 11,12: AgNPs plus $\mathrm{CCl}_{4}$, lanes 13,14: SNLE plus $\mathrm{CCl}_{4}$ and Lanes 15,16: $\mathrm{AgNPs}$ plus $\mathrm{CCl}_{4}$ and SNLE.

\section{Effect of different treatments on mRNA gene expression}

The mRNA expression of GPx (Fig. 6) and SOD (Fig. 7) were measured by semi-quentitative PCR. The results showed that the expression of the two antioxidant enzymes were decreased significantly in animals treated with $\mathrm{AgNPs}$ and/or $\mathrm{CCl}_{4}$ compared to the control group. On the other hand, the expression of either GPx or SOD enzymes were increased significantly in the animals treated with the extract alone. Animals treated with AgNPs and/or $\mathrm{CCl}_{4}$ plus $S$. nigrum showed a significant improvement in GPx and
SOD gene expression however they were still lower than the control value.

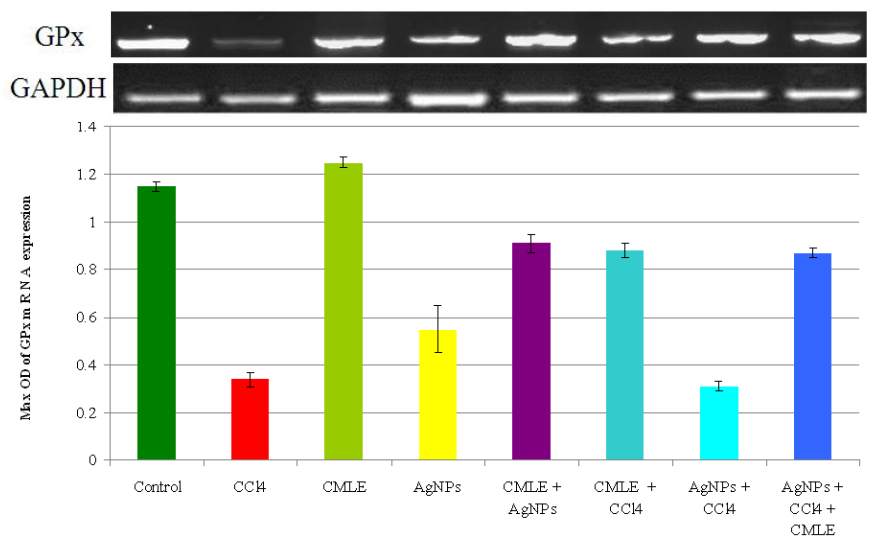

Fig. 6: Effect of S. nigrum leaves extract (SNLE) on GPx gene expression level in liver of rats treated with AgNPs and/or $\mathrm{CCl}_{4}$. The results illustrated are normalized to the level of GAPDH level and the data are the mean of intensity for each gene divided by that for GAPDH.

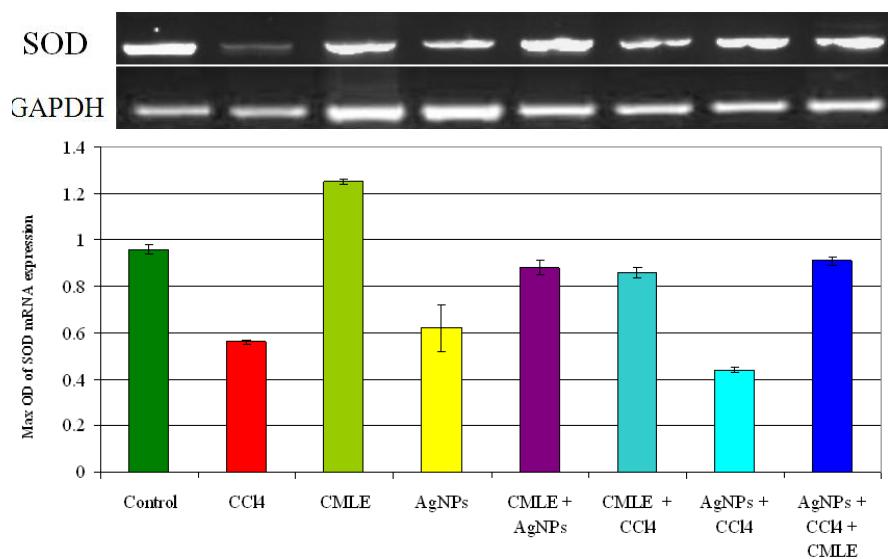

Fig. 7: Effect of S. nigrum leaves extract (SNLE) on SOD gene expression level in liver of rats treated with $\mathrm{AgNPs}$ and/or $\mathrm{CCl}_{4}$. The results illustrated are normalized to the level of GAPDH level and the data are the mean of intensity for each gene divided by that for GAPDH.

The histological examination of the liver tissue of the control rats showed normal hepatic lobules formed of radially arranged cords of liver cells extended from the central vein, separated by blood sinusoid (Fig. 8a). The microscopic examination of the liver sections of rats treated with $\mathrm{CCl}_{4}$ showed sever vacuolar degeneration of cytoplasm of hepatocytes, while nuclei were polymorphism as well as pyknotic (arrows), karyorrhecttic and apoptotic manifested by eosinophilc cytoplasm and condensed nuclei (Fig. 8b). The liver of rat treated with AgNPs showed vacuolar degeneration of cytoplasm of hepatocytes foci of necrosis, nuclei of different forms of degeneration and pyknosis, kryolysis especially eosnophilic cytoplasm (Fig. 8c). The liver section of rats treated with the extract alone showed some degeneration of hepatocytes cytoplasm, multiple foci of necrosis and pyknosis nuclei as well as forms of nuclear degeneration around nodule of inflammatory cell infiltration (Fig. 8d). 

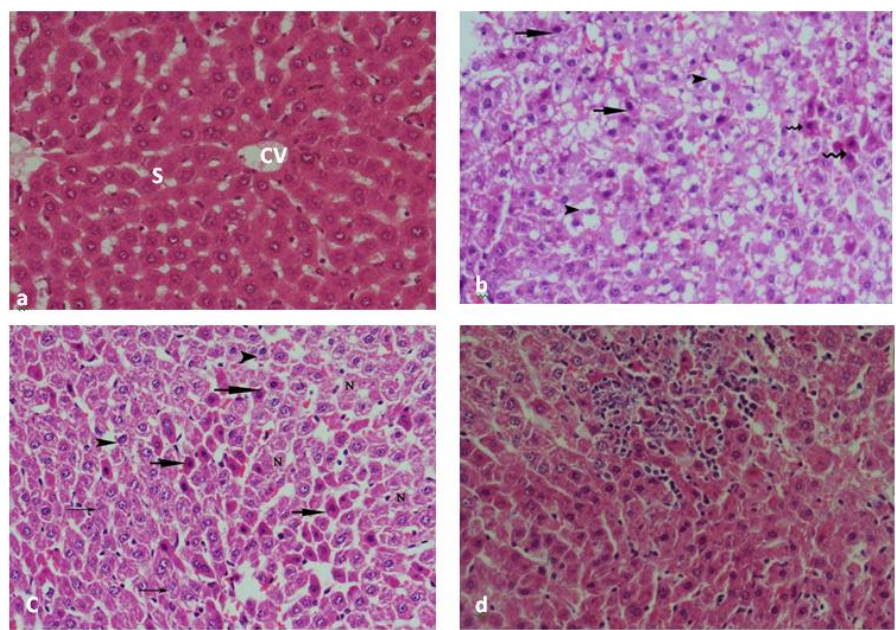

Fig. 8: Photomicrograph of liver section of (a) normal control rats showing normal hepatic lobules formed of radially arranged cords of liver cells extended from the central vein (cv), separated by blood sinusoid, (b) rats treated with $\mathrm{CCl}_{4}$ showing sever vacuolar degeneration of cytoplasm of hepatocytes (arrowheads), while nuclei were polymorphism as well as pyknotic (arrows), karyorrhecttic and apoptotic manifested by eosinophilc cytoplasm and condensed nuclei (weave arrows), (c) rat treated with AgNPs showing vacuolar degeneration of cytoplasm of hepatocytes foci of necrosis $(\mathrm{N})$, nuclei of different forms of degeneration, pyknosis (arrowe head), kryolysis (thin arrows), especially eosnophilic cytoplasm and (d) rats treated with the extract alone showing some degeneration of hepatocytes cytoplasm, multiple foci of necrosis, pyknosis nuclei as well as forms of nuclear degeneration around nodule of inflammatory cell infiltration.
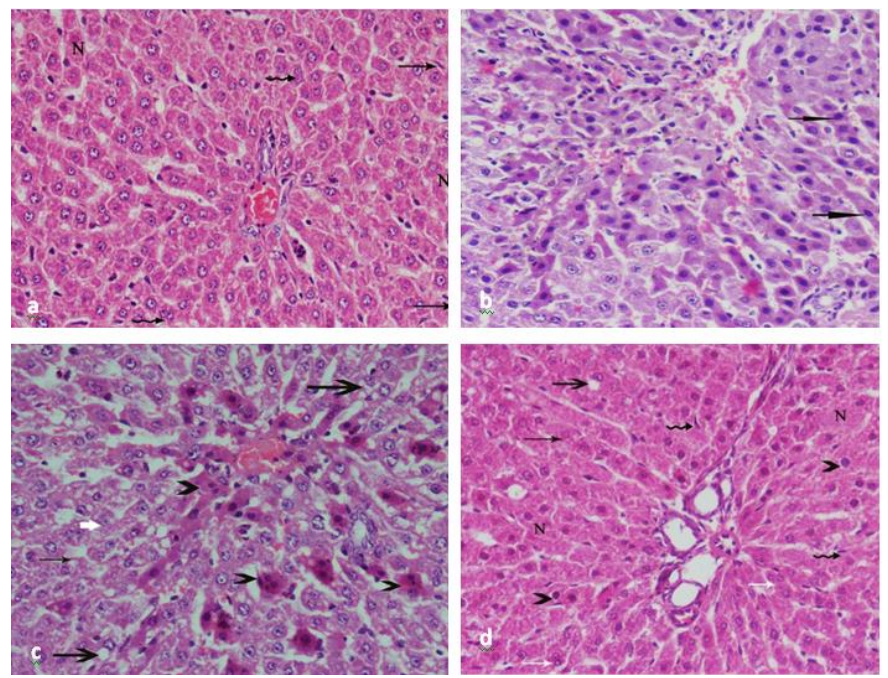

Fig. 9: Photomicrograph of liver section of (a) rats treated with AgNPs plus the $S$. nigrum extract showing congested central vein, multiple areas of necrosis $(\mathrm{N})$, foci of inflammatory cells infiltration invade sinusoid, increase in hypertrophied kupffer cells (thin arrows), increase in binucleation (weavy arrows) could be observed, (b) rats treated with $\mathrm{AgNPs}$ plus $\mathrm{CCl}_{4}$ showing swelling of the hepatocytes, degeneration, congestion and dilation of blood vessels, mononuclear inflammatory cells observed in sinusoids, marked of nuclear degeneration in the form of necrosis $(\mathrm{N})$, kryolysis, condensed chromatin (arrows), and prominent diffuse of basophilic, eosinophilic cytoplasm in hepatocytes around portal area, (c) rat treated with $\mathrm{CCl}_{4}$ plus $S$. nigrum extract showing hepatocytes suffered from fatty degeneration (arrow) beside vacuolar degeneration (thin arrow) scattered in some hepatocytes, of liver lobules, congested central vein with cellular infiltrates, nuclear damage (white arrow) as well as apoptotic cells manifested by eosinophilc cytoplasm with dark nuclei (arrowheads) still present and (d) proliferated bile ducts, fatty degeneration, nuclear damage (pyknotic, keryolysis and focal necrosis), few hepatocytes with binucleation also noticed.
The examination of liver sections of rats treated with AgNPs plus the extract showed congested central vein, multiple areas of necrosis, foci of inflammatory cells infiltration invade sinusoid, increase in hypertrophied kupffer cells and increase in binucleation could be observed (Fig. 9a).

However, the liver sections of rats treated with AgNPs plus $\mathrm{CCl}_{4}$ showed swelling of the hepatocytes, degeneration, congestion and dilation of blood vessels, mononuclear inflammatory cells observed in sinusoids, marked of nuclear degeneration in the form of necrosis, kryolysis, condensed chromatin, prominent diffuse of basophilic and eosinophilic cytoplasm in hepatocytes around portal area (Fig. 9b). the liver sections of rat treated with $\mathrm{CCl}_{4}$ plus plant extract showed that the hepatocytes suffered from fatty degeneration beside vacuolar degeneration scattered in some hepatocytes of liver lobules, congested central vein with cellular infiltrates and nuclear damage as well as apoptotic cells manifested by eosinophilc cytoplasm with dark nuclei was still present (Fig. 9c). The liver section of animals treated with AgNPs plus $\mathrm{CCl}_{4}$ and the plant extract showed proliferated bile ducts, fatty degeneration, nuclear damage (pyknotic, keryolysis and focal necrosis) and few hepatocytes with binucleation also noticed (Fig. 9d).

\section{DISSCUSTION}

The wide use of AgNPs may increase the potential accumulation of AgNPs in the food chain (Oberdörster et al., 2005) resulting in organ toxicity to alive organism. In general, the toxicity of different sizes of AgNPs was evaluated in vitro but to less extent in vivo studies. Consequently, the potential effects of AgNPs in humans remain poorly understood. In the current study, AgNPs were synthesized using the water extract of $S$. nigrum leaves suggesting that the extract was able to reduce silver ions to AgNPs when incubated for $24 \mathrm{~h}$ in dark. The change in color from yellow to reddish brown indicated the formation of AgNPs. The change in color of $\mathrm{AgNO}_{3}$ has been observed by several investigators and suggesting that the change in color appeared due to the surface plasmon resonance of deposited AgNPs (Khandelwal et al., 2010; Saxena et al., 2010; Abdel-Aziz et al., 2014). The TEM analysis showed that the sizes of the synthesized AgNps ranged from $30-50 \mathrm{~nm}$ and confirmed the formation of AgNPs. In the current study, animals treated with AgNPs showed sever toxicity to liver and kidney as indicated by the elevation of serum enzymes activity, kidney function tests, the proinflammatory mediator TNF- $\alpha$ and oxidative stress markers (NO and MDA) accompanied with the significant decrease in antioxidant enzymes activity. Although the toxicity resulted from AgNPs was lower than that resulted from $\mathrm{CCl}_{4}$, but the general conclusion revealed that these AgNPs can induce liver damage after the exposure even for short time period. The results of the current study are consistent with previous reports with respect to the liver as the target organ after oral administration of AgNPs which was found to increase ALT, AST, ALP and GGT (Kim et al., 2007; Sung et al., 2008). The significant decrease in GSH, 
CAT and TAC level accompanied with a significant increase in MDA, NO and TNF- $\alpha$ in serum of rats treated with AgNPs compared with control group reported herein suggesting that AgNPs induced to oxidative stress and supported the previous results of other investigators (Arora et al., 2009). One of the most important mechanisms of AgNPs-induced toxicity is the generation of reactive oxygen species (ROS) resulted in oxidative stress. Oxidative stress is subsequent production of inflammatory mediators, DNA damage and apoptosis (Ryter et al., 2007; El Mahdy et al., 2014). In this concern, Kim et al. (2010) suggested that AgNPs increase the levels of ROS, lipid peroxidation and decrease GPx as a mechanism of liver damage. Moreover, AgNPs caused membrane damage, leakage of lactate dehydrogenase, reduction in glutathione peroxide and superoxidase dismutase activity and cell viability in human hepatoma cell line (HL-7702) (Song et al., 2012).

Regarding to $\mathrm{CCl}_{4}$ as a model for studying free radicalinduced liver injury, several studies have reported the involvement of oxidative stress in $\mathrm{CCl}_{4}$-induced liver damage (Nogueira et al., 2009; Ma et al., 2012). The liver damage caused by $\mathrm{CCl}_{4}$ is characterized by inflammation in early stage. In the damaged hepatocytes, $\mathrm{CCl}_{4}$ is metabolized by cytochrome $\mathrm{P} 450$ into trichloromethyl radical, a highly reactive species that triggers lipid peroxidation and lead to hepatotoxicity (Deng et al., 2012). The toxic effects of $\mathrm{CCl}_{4}$ reported herein were similar to those reported in the literature. Animals treated with $\mathrm{CCl}_{4}$ alone or in combination with AgNPs showed an elevation in the proinflammatory mediator TNF- $\alpha$ suggesting chronic hepatotoxicity (Bruccoleri et al., 1997). TNF- $\alpha$ is a central regulator for many bioactive molecules including those responsible for chronic inflammation, induction of acute phase proteins, cell proliferation and cytotoxicity and its elevated expression is associated with potentiating hepatotoxicity.

In the current study, liver damage induced by $\mathrm{CCl}_{4}$ and/or AgNPs was confirmed by DNA fragmentation percentage and DNA ladder assay banding pattern and revealed cellular correlates of damage after $\mathrm{CCl}_{4}$ and/or AgNPs administration. On the other hand, $\mathrm{CCl}_{4}$ is well known to degrade DNA in liver tissue of rats by generating free radicals and increase DNA fragmentation (Alkreathy et al., 2014). Regarding the gene expression level, the current findings indicated that, $\mathrm{CCl}_{4}$ induced down-regulation of the examined antioxidant enzymes (SOD and GPx) gene expression and liver fibrosis in mice (Chen et al., 2013). The genotoxic effects of AgNPs were represented by the increase in DNA fragmentation and the disturbance of gene expression which may be attributed to oxidative stress created by AgNPs exposure. The genotoxicity of AgNPs was evaluated by various in vitro and in vivo studies and confirmed the findings obtained in the current study and suggested that AgNPs cause chromosomal aberrations and DNA damage and capable to induce proliferation arrest in rats and human cell lines (Ji et al., 2007; Asharani et al., 2009) although the exact mechanism through which AgNPs induce genotoxicity still remains unclear. Asharani et al. (2009) found that AgNPs can damage DNA indirectly by increasing ROS production or by decreasing ATP production inducing mitochondrial damage which impairs energy-dependent DNA repair mechanisms. Moreover, Cha et al. (2008) and Yang et al. (2009) suggested that direct DNA damage occurred by Ag+ released from AgNPs themselves. Furthermore, it was reported that AgNPs increase DNA-strand breaks in human testicular embryonic carcinoma cells by increase ROS production (Asare $e t$ al., 2012). The mechanism of AgNPs induced hepatotoxicity was discussed by Sardari et al. (2012) who suggested that the removing of nanoparticles from the liver by macrophages due to phagocytosis process and the repetition of this process produces higher oxygen radicals. On the other hand, Loghman et al. (2012) concluded that the cytotoxicity of AgNPs is mainly due to the mitochondrial activity which is decreased with the increase in the concentration of AgNPs inducing drastic reduction of mitochondrial function, increased membrane leakage, necrosis and induction of apoptosis.

The histopathological examination of liver revealed that various alterations denoting the hepatotoxic effect of AgNPs and/or $\mathrm{CCl}_{4}$ including vacuolar degeneration of the cytoplasm in the hepatocytes, foci of necrosis, nuclei of different forms of degeneration, pyknosis, karyolysis especially eosnophilic cytoplasm and dark nuclei. Similar necrosis, hepatocellular degeneration, and individual apoptosis were reported and confirmed that the liver is the target organ for the effect of AgNPs (Sung et al., 2008; Kim et al., 2010; El Mahdy et al., 2014).

Treatment with $S$. nigrum significantly lowered the elevation of hepatic enzyme markers, kidney indices induced by $\mathrm{CCl}_{4}$ and/or AgNPs as well as decreased MDA and DNA fragmentation in the liver tissue. The extract also increased the antioxidant capacity and decreased the inflammatory cytokines consequently, repressed the production of free radicals and the subsequent liver damage (Raju et al., 2003). Similar to these observations, Lin et al. (2008) reported that S. nigrum extract protects the liver against $\mathrm{CCl}_{4}$-induced oxidative damage in the liver through its the high content of polyphenols, alkaloids and saponins which contributes free radical scavenging and antioxidation activities. The hepatoprotective effect of the $S$. nigrum leaves extract reported in the current study suggested that these compounds play an important role in plasma membrane stabilization and the repairing of liver damage caused by $\mathrm{CCl}_{4}$ and/or AgNPs. Furthermore, the phenolic compounds contribute directly to antioxidative action (Awika et al., 2003) probably due to their redox properties which allow them to act as hydrogen donors, reducing agents and singlet oxygen quenchers (Chang et al., 2001). The extract also showed a significant decrease in cytokine level and the inflammation process indicated that it has anti-inflammatory properties via decreasing the ROS generation which involved in inflammation process (Ravi et al., 2009). Moreover, Hsu et al. (2009) reported that S. nigrum increased expression of glutathione S-transferase-alpha and -mu, the level of transcription factor $\mathrm{Nrf2}$, glutathione peroxidase, superoxide dismutase-1, and catalase. These results are in agreement with previous studies that have reported hepatoprotective and 
antioxidant effects of extracts containing flavonoids and other phenolic compounds (Kukrić et al., 2012; Abdel-Aziz et al., 2014). Taken together, strengthening the antioxidant defense system and the free radical scavenging activity can result in positive curative effects on liver injuries (Nagalekshmi et al., 2011). Moreover, Padmashree et al. (2014) reported that $S$. nigrum leaves extract is rich in mineral content $(\mathrm{Cu}, \mathrm{Fe}, \mathrm{Na}, \mathrm{K}, \mathrm{Zn}$, $\mathrm{Cu}, \mathrm{Mg}$ and $\mathrm{P}$ ) and nutrition composition (ascorbic acid, total carotenoids, total chlorophyll, total phenols, total flavonoids and total tocopherol) which have great potential as natural antioxidants. Similar results were reported by Das et al. (2015) who suggested higher total phenol and total falvonoid content in $S$. nigrum leaves extract. Moreover, Aboul-Enein et al. (2014) isolated 8 active compounds identified as Naphtho [2,1-b]furan2(1H)-one, 2,3 Dihydroxypropyl elaidate, 5Bromosalicylaldehyde, 12-sulfanyldodecanoic acid Usnic acid monoacetate, decahydro-3a,6,6,9a-tetramethy, 8-Azabicyclo [3.2.1] octane-2-carboxylic acid, 3-hydroxy-8-methyl,(2-endo,3exo), Niclofen, and Trilinolein. These compounds also showed a potent antioxidant and anticancer activity.

\section{CONCLUSION}

AgNPs can be synthesized simply using $S$. nigrum leaves extract in a size ranged from $30-50 \mathrm{~nm}$. S. nigrum leaves extract was found to be rich in total phenolic compounds, total flavonides and $\beta$-carotene. AgNPs affect negatively the liver function enzymes, oxidative stress markers, antioxidant parameters, tumor markers, DNA fragmentation and antioxidant gene expression indicating the hepatotoxic and genotoxic effect. These hepatotoxic and genotoxic effects resulted when rats treated with $50 \mathrm{mg} / \mathrm{kg} \mathrm{b.w}$ for three weeks and particles size ranged from 30-50 nm. However, this toxicity was less than that caused by $\mathrm{CCl}_{4}$ at the tested dose of $0.1 \mathrm{ml} / \mathrm{kg}$ b.w. S. nigrum leaves extract succeeded to counteract these toxic effects due to its higher content of phenolic and flavonoid compounds which exhibited antioxidant and free radical scavenging activities. S. nigrum leaves may be promise candidate to be used as a hepatoprotectant against AgNPs-induced hepatotoxicity.

\section{ACKNOWLEDGMENTS}

Financial support and sponsorship: This work was supported by the National Research Centre, Dokki, Cairo, Egypt project \# 10070112 and the Faculty of Pharmacy, Cairo University, Cairo, Egypt.

Conflict of Interests: There are no conflicts of interest.

\section{REFERENCES}

Abdel-Aziz MS, Shaheen MS, El-Nekeety AA, Abdel-Wahhab MA. Antioxidant and antibacterial activity of silver nanoparticles biosynthesized using Chenopodium murale leaf extract. J Saudi Chem Soc, 2014; 18: 356-363.

Aboul-Enein AM, Abu El-Ela F, Shalby E, El-Shemy H. Potent anticancer and antioxidant activities of active ingredients separated from $S$. nigrum and cassia italica extracts. J Arid Land Studies, 2014; 24(1): 145 152.

Alkreathy HM, Khan RA, Khan MR, Sahreen S. $\mathrm{CCl}_{4}$ induced genotoxicity and DNA oxidative damages in rats: Hepatoprotective effect of Sonchus arvensis. J BMC Complement Altern Med, 2014; 14: 452.

Arora S, Jain J, Rajwade JM, Paknikar KM. Interactions of silver nanoparticles with primary mouse fibroblasts and liver cells. Toxicol. Appl Pharmacol, 2009; 236: 310-318.

Asare N, Instanes C, Sandberg WJ. Cytotoxic and genotoxic effects of silver nanopar-ticles in testicular cells. Toxicology, 2012; 291: $65-72$.

Asharani PV, Low Kah Mun G, Hande MP, Valiyaveettil S. Cytotoxicity and genotoxicity of silver nanoparticles in human cells. ACS Nano, 2009; 3(2): 279-290

Awika JM, Rooney LW, Wu X, Prior RL, Zevallos LC. Screening methods to measure antioxidant activity of sorghum (Sorghum bicolor) and sorghum products. J Agric Food Chem, 2003; 51: 6657-6662.

Ayala-Nú nez NV, Lara HH, Turrent Liliana del CI, Padilla CR. Silver nanoparticles toxicity and bactericidal effect against Methicillinresistant Staphylococcus aureus:nanoscale does matter. Nanobiotechnol, 2009; 5: 2-9.

Braydich-Stolle L, Hussain S, Schlager JJ, Hofmann MC. In vitro cytotoxicity of nanoparticles in mammalian germline stem cells. Toxicol Sci, 2005; 88: 412-419.

Bruccoleri A, Gallucci R, Germolec DR, Blackshear P, Simeonova P, Thurman RG, Luster MI. Induction of early immediate genes by tumor necrosis factor $\alpha$ contribute to liver repair following chemical induced hepatotoxicity. J Hepatol, 1997; 25:133-141.

Cha K, Hong HW, Choi YG, Lee MJ, Park JH, Chae HK, Ryu $\mathrm{G}$, Myung H. Comparison of acute responses of mice livers to short-term exposure to nano-sized or micro-sizedsilver particles. Biotechnol Lett, 2008; 30: 1893-1899.

Chang ST, Wu JH, Wang SY, Kang PL, Yang NS, Shyur LF. Antioxidant activity of extracts from Acacia confusa bark and heartwood. J Agric Food Chem, 2001; 49: 3420-3424.

Chen $\mathrm{S}$, Zou $\mathrm{L}$, Li $\mathrm{L}, \mathrm{Wu} \mathrm{T}$. The protective effect of glycyrrhetinic acid on carbon tetrachloride-induced chronic liver fibrosis in mice via upregulation of Nrf2. PLoS One, 2013; 8: doi: 10.1371.

Das S, Jamal S, Dutta M, Rej S, Chatterjee S. Comparative phytochemical analysis and antimicrobial activity of four medicinal plants. E J M Plants, 2015; 6(4): 191-199.

Deng JS, Chang YC, Wen CL, Liao JC, Hoa WC, Amagaya S, Huang SS, Huang GJ. Hepatoprotective effect of the ethanol extract of Vitis thunbergii on carbon tetrachloride induced acute hepatotoxicity in rats through antioxidative activities. J Ethnopharmacol, 2012; 142: $795-$ 803.

Drury RA, Wallington EA. Carleton's Histological Technique. $5^{\text {th }}$ Edition, 1980; Oxford University Press, New York.

Dwivedi AD, Gopal K. 2011. Plant-mediated biosynthesis of silver and gold nanoparticles. J Biomed Nanotechnol, 2011; 7(1): 163-164.

El Mahdy MM, Eldin TA, Aly HS, Mohammed FF, Shaalan MI. Evaluation of hepatotoxic and genotoxic potential of silver nanoparticles in albino rats. Exp Toxicol Pathol, 2014; 67(1): 21-29.

Elavazhagan T, Arunachalam KD. 2011. Memecylon edule leaf extract mediated green synthesis of silver and gold nanoparticles, Int J Nanomed, 2011; 6: 1265-1278.

Feng Y, Siu KY, Ye X, Wang N, Yuen MF, Leung CH, Tong Y, Kobayashi S. 2010. Hepatoprotective effects of berberine on carbon tetrachloride induced acute hepatotoxicity in rats. Chin Med, 2010; 5: 33 38 .

Gibb RI, Taylor DD, Wan T, O'Connor DM, Doeriog DL, GerHel-Taylor T. 1997. Apoptosis as a measure of chemosensitivity to cisplatin and taxol therapy in ovarian cancer cell lines. Gynecolog Oncol, 1997; 65: 13-22.

Holtz RD, Lima BA, Souza Filho AG, Brocchi M, Alves OL. 2012. Nanostructured silver vanadate as a promising antibacterial additive to water-based paints. Nanomed Nanotechnol Biol Med, 2012; 6: 935-40.

Hsu JD, Kao SH, Tu CC, Li YJ, Wang CJ. Solanum nigrum L. extract inhibits 2-acetylaminofluorene-induced hepatocarcinogenesis 
through overexpression of glutathione S-transferase and antioxidant enzymes. J Agric Food Chem, 2009; 57(18): 8628-8634.

Ji JH, Jung JH, Kim SS, Yoon JU, Park JD, Choi BS, Chung YH, Kwon IH, Jeong J, Han BS, Shin JH, Sung JH, Song KS, Yu IJ. Twenty-eight-day inhalation toxicity study of silver nanoparticles in Sprague Dawley rats. Inhal Toxicol, 2007; 19(10): 857-871.

Jia HY, Liu Y, Zhang XJ, Han L, Du LB, Tian Q. Potential oxidative stress of gold Nanoparticles by induced-NO releasing in serum. $\mathrm{J}$ Am Chem Soc, 2009; 131(1): 40-41.

Judzentiene A, Garjonyte R, Budiene J. Variability, toxicity, and antioxidant activity of Eupatorium cannabinum (hemp agrimony) essential oils. Pharm Biol, 2015; 6: 1-9.

Khandelwal N, Singh A, Jain D, Upadhyay MK, Verma HN. Green synthesis of silver nanoparticles using Argimone maxicana leaf extract and evaluation of their activity. Dig J Nanomater Bios, 2010; 5: 483-489.

Kim DO, Jeong SW, Lee CY. Antioxidant capacity of phenolics phytochemicals from various cultivars of plums. Food Chem, 2003; 81(3): 321-326.

Kim JS, Kuk E, Yu KN, Kim JH, Park SJ, Lee HJ, Kim SH, Park YK, Park YH, Hwang CY, Kim YK, Lee YS, Jeong DH, Cho MH. Antimicrobial effects of silver nanoparticles. Nanomed, 2007; 3: 95-101.

Kim YS, Kim JS, Cho HS, Rha DS, Kim JM, Park JD, Choi BS, Lim R, Chang HK, Chung YH, Kwon IH, Jeong J, Han BS, Yu IJ. Twenty-eight day oral toxicity, genotoxicity and gender related tissue distribution of silver nanoparticles in Sprague Dawley rats. Inhal Toxicol, 2008; 20(6): 575-583.

Kim YS, Song MY, Park JD, Song KS, Ryu HR, Chung YH, Chang HK, Lee JH, Oh KH, Kelman BJ, Hwang IK, Yu IJ. Subchronic oral toxicity of silver nanoparticles. Part Fiber Toxicol, 2010; 7(1): 20.

Kukrića ZZ, Topalić-Trivunović LN, Kukavica BM, Matoš SB, Pavičić S, Boroja MM, Savić AV. Charaterization of antioxidant and antimicrobial activities of nettle leaves (Urtica dioica L.). BIBLID, 2012; 43: 257-271.

Leela A, Vivekanandan M. Tapping the unexploited plant resources for the synthesis of silver nanoparticles. Afr J Biotechnol, 2008; 7: 3162-3165.

Lin CC, Hsu YF, Lin TC, Hsu FL, Hsu HY. Antioxidant and hepatoprotective activity of punicalagin and punicalin on carbon tetrachloride induced liver damage in rats. J Pharmacol, 1998; 50: 789794.

Lin HM, Tseng HC, Wang CJ, Lin JJ, Lo CW, Chou FP. Hepatoprotective effects of Solanum nigrum Linn extract against $\mathrm{CCl}_{4}$ induced oxidative damage in rats. Chem Biol Interact, 2008; 171(3):28393.

Loghman A, Iraj SH, Naghi DA, Pejman M. Histopathologic and apoptotic effect of nanosilver in liver of broiler chickens?. Afr J Biotechnol, 2012; 11(22): 6207-6211.

Lu T, Xu Y, Mericle MT, Mellgren RL. Participation of the conventional calpains in apoptosis. Biochimica et Biophysica Acta, 2002; 1590: $16-26$

Lv Y, Liu H, Wang Z, Liu S, Hao L, Sang Y, Liu D. 2009. Silver nanoparticle-decorated porousceramic composite for water treatment. J Membr Sci, 2009; 331: 50-56.

Ma L, Gan D, Wang M, Zhang Z, Jiang C, Zeng X. Optimization of extraction, preliminary characterization and hepatoprotective effects of polysaccharides from Stachys floridana Schuttl. ex corosolic acid: Carbohydr Polym, 2012; 87: 1390-1398.

MacNee W, Donaldson K. Mechanism of lung injury caused by PM10 and ultrafine particles with special reference to COPD. Eur Respir J, 2003; 21(40): 47S-51S.

Mehrbod P, Motamed N, Tabatabaian M, Soleimani R, Amini E, Shahidi M, Kheiri MT. In vitro antiviral effect of nanosilver on influenza virus. DARU, 2009; 17: 88-93.

Miguel MG, Gago C, Antunes MD, Megías C, Cortés-Giraldo I, Vioque J, Lima AS, Figueiredo AC. Antioxidant and antiproliferative activities of the essential oils from Thymbra capitata and Thymus Species
Grown in Portugal. Evid Based Complement Alternat Med, 2015; doi: $10.1155 / 2015 / 851721$

Nagalekshmi R, Menon A, Chandrasekaran DK, Nair CK. Hepatoprotective activity of Andrographis paniculata and Swertia chirayita. Food Chem Toxicol, 2011; 49: (12): 3367-3373

Nair B, Pradeep T. Coalescence of nanoclusters and formation of submicron crystallites assisted by Lactobacillus Strains cryst. Growth Des, 2002; 2: 293-298.

Nogueira CW, Borges LP, Souza AC. 2009. Oral administration of diphenyl diselenide potentiates hepatotoxicity induced by carbon tetrachloride in rats. J Appl Toxicol, 2009; 29: 156-164.

Oberdörster G, Maynard A, Donaldson K, Castranova V, Fitzpatrick J, Ausman K, Carter J, Karn B, Kreyling W, Lai D, Olin S, Monteiro-Riviere N, Warheit D, Yang H. 2005. Principles for characterizing the potential human health effects from exposure to nanomaterials: elements of a screening strategy. Part Fiber Toxicol, 2005; 2: 8 .

Padmashree A, Sharma GK, Semwal AD, Mahesh C. Antioxygenic activity of solanum nigrum L. leaves in sunflower oil model system and its thermal stability. Food Nutr Sci, 2014; 5: 1022 1029 .

Park EJ, Bae E, Yi J, Kim Y, Choi K, Lee SH, Yoon J, Lee BC, Park K. Repeated-dose toxicity and inflammatory responses in mice by oral administration of silver nanoparticles. Environ Toxicol Pharmacol, 2010; 30: 16-18.

Quaresma P, Soares L, Contar L, Miranda A, Osorio I, Carvalho PA, Franco R, Pereira E. Green photocatalytic synthesis of stable Au and Ag nanoparticles. Green Chem Comm, 2009; 11: 1889-1893.

Raben N, Nichols RC, Martiniuk F, Plotz PH. A model of mRNA splicing in adult lysosomal storage disease Glycogenosis type II. Hum Mol Genet, 1996; 5: 995-1001.

Raut RW, Kolekar NS, Lakkakula JR, Mendhulkar VD, Kashid SB. Extracellular synthesis of silver nanoparticles using dried leaves of Pongamia pinnata (L) Pierre. Nano Micro Lett, 2010; 2: 106113.

Ravi V, Saleem TSM, Patel SS, Raamamurthy J, Gauthaman K. Anti-Inflammatory effect of methanolic extract of Solanum nigrum Linn berries. Int. J Appl Res Nat Prod, 2009; 2(2); 33-36.

Ryter SW, Kim HP, Hoetzel A, Park JW, Nakahira K, Wang X, Choi AM. Mechanisms of cell death in oxidative stress. Antioxid Redox Signal, 2007; 9: 49-89.

Sardari RRR, Zarchi SR, Talebi A, Nasri S, Imani S, Khoradmehr A, Sheshde SAR. Toxicological effects of silver nanoparticles in rats. Afr J Microbiol Res, 2012; 6(27): 5587-5593.

SAS institute, Inc. SAS Users Guide: Statistics. SAS Institute, Cary, NC, 1982

Saxena A, Tripathi RM, Singh RP. Biological synthesis of silver nanoparticles by using onion (Allium cepa) extract and their antibacterial activity. Digest J Nanomater Bios, 2010; 5: 427-432.

Singh RP, Murthy KNC, Jayaprakasha GK. Studies on the antioxidant activity of pomegranate (Punica granatum) peel and seed extracts using in vitro models. J Agric Food Chem, 2002; 50: 81 86.

Song XL, Li B, Xu K, Liu J, Ju W, Wang J, Liu XD, Li J, Qi YF. Cytotoxicity of water soluble mPEG-SH-coated silver nanoparticles in HL-7702 cells. Cell Biol Toxicolm, 2012; 28(4): 225-237.

Sung JH, Ji JH, Park JD, Yoon JU, Kim DS, Jeon KS, Song MY, Jeong J, Han BS, Han JH, Chung YH, Chang HK, Lee JH, Cho MH, Kelman BJ, Yu IJ. 2008. Subchronic inhalation toxicity of silver nanoparticles. Toxicol Sci, 2008; 108: 452-461.

Tang J, Xi T. Status of biological evaluation on silver nanoparticles. Sheng Wu Yi Xue Gong Cheng Xue Za Zhi, 2008; 25(4): 958-961.

Tsibakhashvili N, Kalabegishvili T, Gabunia V, Gintury E, Kuchava N, Bagdavadze N, Pataraya D, Gurielidzse M, Gvarjaladze D, Lomidze L. Synthesis of silver nanoparticles using bacteria. Nano Stud, 2010; 2: 179-182.

Waller RA, Duncan DB. A Bayes rule for the symmetric multiple comparison problems. J Am Stat Assoc, 1969; 64: 1484-1503. 
Wettasinghe M, Shahidi F. Evening primrose meal: a source of natural antioxidants and scavenger of hydrogen peroxide and oxygen derived free radicals. J Agric Food Chem, 1999; 47(5): 1801 1812.

Wiame I, Remy S, Swennen R, Sági L. Irreversible heat inactivation of DNaseI without RNA degradation, Biotechniques, 2000; 29: 252-256.

Willner I, Baron, R, Willner B. Growing metal nanoparticles by enzyme. Adv Mater, 2006; 18(9): 1109-1120.

Wong KK, Cheung SO, Huang L, Niu J, Tao C, Ho CM. 2009. Further evidence of the anti-inflammatory effects of silver nanoparticles. Chem Med Chem, 2009; 4: 1129-1135.

Yang W, Shen C, Ji Q, An H, Wang J, Liu Q, Zhang Z. 2009. Food storage material silver nanoparticles interfere with DNA replication fidelity and bind with DNA. Nanotechnol, 2009; 20: 085102.

\section{How to cite this article:}

Abdel-Wahhab MA, Ahmed HMS, Abdel-Aziem SH, El-Nekeety AA, Abdel-Kader HAM, Abdel-Aziz MS, Sharaf HA, Naguib HM, El-Denshary ES. Modulation of hepatotoxicity, DNA fragmentation and gene expression of Solanum nigrum leaves extract in rats treated with silver nanoparticles. J App Pharm Sci, 2017; 7 (02): 025-035. 